\title{
Intrapopulation variation in habitat use by two abundant coastal fish species
}

\author{
Caroline M. Hammerschlag-Peyer*, Craig A. Layman \\ Marine Sciences Program, Department of Biological Sciences, Florida International University, 3000 N.E. 151st Street, \\ North Miami, Florida 33181, USA
}

\begin{abstract}
Decline of marine fisheries has become one of the most severe global environmental crises. In typical fishery management efforts, fish populations are often treated as homogeneous units, thereby tacitly ignoring potential intrapopulation variation within taxonomic groupings. We used acoustic telemetry and stable isotope analysis to examine movement patterns of 20 gray snapper Lutjanus griseus and 20 schoolmaster snapper L. apodus in a Bahamian tidal creek and wetland. In particular, we examined (1) if intrapopulation variation in fish habitat use and movement patterns existed, (2) whether that variation was a function of body size, and (3) if there was evidence of specialization in habitat use among individuals. We found that movement varied substantially among individuals, but was independent of body size. Some individuals exhibited frequent, repeated, movements to certain areas of the study site. $\delta^{13} \mathrm{C}$ values of individual snapper were significantly related to movement metrics, suggesting that movement differences were related to specific patterns of foraging behavior. Our findings suggest the importance of incorporating intrapopulation niche variation-a source of variation that is often overlooked in traditional conservation and management strategies - into the study of coastal fish populations.
\end{abstract}

KEY WORDS: Behavioral ecology · Body size $\cdot$ Fisheries · Food web · Individual specialization · Movement patterns $\cdot$ Optimal foraging theory $\cdot$ Stable isotopes

Resale or republication not permitted without written consent of the publisher

\section{INTRODUCTION}

Overexploitation of marine fishes is considered one of the most critical global environmental crises (Jackson et al. 2001, Worm et al. 2006). Stocks of economically and ecologically important species have been drastically reduced through commercial and recreational fisheries (Coleman et al. 2004, Lotze \& Worm 2009). Although large pelagic predators are especially susceptible to declines (Pauly et al. 1998, Heithaus et al. 2008), populations of coastal mesopredators such as groupers (Serranidae) and snappers (Lutjanidae) are also threatened by overexploitation (Willis et al. 2001, Nieland et al. 2007, Graham et al. 2008). For example, populations of the Nassau grouper Epinephelus striatus have declined by up to $60 \%$ over the last 3 decades and the species has been added to the IUCN Red List (Baillie \& Groombridge 1996, Sadovy 1997).

In order to provide a template for developing conservation and management strategies, scientists usually seek to identify broad generalities that define the 'typical' individual of a particular population. Individuals are assumed to possess generally the same behavioral or feeding traits during certain life stages or size classes, and a population is thus treated as a homogeneous unit from a management perspective. One wellknown example are juvenile grunts (Haemulidae) in Teague Bay, US Virgin Islands, which rest over coral heads during the day and move to seagrass beds as a group at night (Meyer et al. 1983). Similarly, gray snapper Lutjanus griseus in Biscayne Bay, Florida have been observed to move in groups from mangroves during the day to seagrass beds at night (Luo et al. 2009). With respect to ontogeny, individuals of many reef fishes are assumed to go through predictable sequences of habitat utilization (Nagelkerken et al. 2000). For instance, larval French grunts Haemulon flavolineatum in Piscadera Bay, Curaçao, settle in sand/rubble habitat at the mouth of bays, move further into the bay to utilize mangroves and seagrass beds as 
juveniles, and then shift to coral reefs as adults (Huijbers et al. 2008).

Despite the common perspective that individuals of a population are homogeneous units, substantial intrapopulation variation in behavior has been shown to occur across diverse taxonomic groups and may have important evolutionary, ecological and conservation implications (Van Valen 1965, Roughgarden 1972, 1974, Schindler et al. 1997, Bolnick et al. 2003). From a management perspective, focusing only on the core habitats of a population may ignore those individuals that utilize alternative habitats or food sources. This can be especially problematic when intrapopulation variation is a function of body size or age, since a demographically important subset of the population may be neglected (Durell 2000, Bolnick et al. 2003). Recognizing intrapopulation variation in fishery management plans may facilitate preserving species' ecological, phenotypic and genetic diversity (Moritz 1994, Coates 2000, Smith et al. 2001, Bolnick et al. 2003).

The aim of this study was to examine potential variation in habitat use and movement patterns among individuals of 2 ecologically and economically important nearshore snapper populations. Specifically, we investigated (1)

if variation in habitat use and movement patterns occurred among individuals of gray snapper Lutjanus griseus and/or schoolmaster snapper L. apodus, (2) whether that variation was a function of body size (a well-acknowledged mechanism of intrapopulation variation), and (3) if there was evidence of specialization in habitat use for either focal population. We used acoustic telemetry to directly explore the movements of fishes at an individual level, as well as stable isotope ratios to provide indirect information as to potential feeding patterns. We endeavored to provide a framework for future research that acknowledges variation in behavioral attributes and foraging within marine populations.

\section{MATERIALS AND METHODS}

Study system and species. Broad Creek $\left(26^{\circ} 29^{\prime}\right.$ $35^{\prime \prime} \mathrm{N}, 77^{\circ} 02^{\prime} 34^{\prime \prime} \mathrm{W}$ ) is an estuarine tidal creek located on the east side of Abaco Island, The Bahamas (Fig. 1).
Tidal creeks in The Bahamas range in size from several hectares with maximum low tide depths of $1 \mathrm{~m}$, to thousands of hectares with maximum depths $>10 \mathrm{~m}$ (Layman et al. 2007, Rypel et al. 2007, Valentine-Rose et al. 2007b); Broad Creek falls at the lower end of this range. The system has a semi-diurnal tidal regime and a mean daily tidal amplitude of $\sim 0.8 \mathrm{~m}$. There is little freshwater input to this system; thus, it is marine-dominated throughout its extent (Valentine-Rose et al. 2007a).

Broad Creek consists of extensive, shallow, intertidal flats. These flats are primarily composed of a silt substrate with interspersed mangroves (mainly Rhizophora mangle). The most prevalent benthic habitat types are seagrass beds (primarily Thalassia testudinum), submerged mangrove prop roots (mostly $R$. mangle), hard bottom with soft corals (mostly Gorgonia spp.) and sand. At low tide, water depths $\sim>0.3 \mathrm{~m}$ are only found in 2 pools ( $10 \mathrm{~m}$ in diameter) in the northwest corner of Broad Creek (Fig. 1). The tidal pools are depressions in the karst substrate that stay inundated 
even at the lowest tides, thereby providing habitat for fishes at all tidal phases (Rypel et al. 2007, ValentineRose et al. 2007b). The majority of the creek area ( $>99 \%$ ) is $<0.3 \mathrm{~m}$ at low tide, and is generally too shallow for adult and subadult snapper to traverse (Rypel et al. 2007).

Gray snapper Lutjanus griseus (Linnaeus 1758) and schoolmaster snapper Lutjanus apodus (Walbaum 1972) are abundant generalist fish predators that coexist in many nearshore ecosystems in the tropics and subtropics of the Atlantic (Starck \& Schroeder 1971, Allen 1985). In Broad Creek, as is common in shallow creeks of The Bahamas, these fishes typically inhabit deeper pools or deep mangrove-lined shorelines, herein referred to as 'home sites' (e.g. HS A and HS B in Fig. 1). Individual fish may leave these home sites with rising water during flood tides, likely to feed, and typically return to the home sites as water levels fall with ebbing tide (Rypel et al. 2007). These repeated daily movements to and from the home sites in Broad Creek provide a unique opportunity to quantitatively evaluate individual level variation in local scale movement patterns.

Tagging and tracking. Twenty gray and 20 schoolmaster snapper were caught at home sites A and B at low tide between 20-28 April 2009 using baited hooks and fish traps. Sizes were representative of those fishes that are found in these systems (Layman et al. 2007, Luo et al. 2009). Small acoustic transmitters (V7, Vemco; $19 \times 7 \mathrm{~mm}, 1.6 \mathrm{~g}$ in air, $77 \mathrm{~d}$ battery life), which pinged every 15 to $45 \mathrm{~s}$, were surgically implanted into each fish. Each transmitter had a unique code to identify individual fish. Individual fish were anesthetized in a mixture of fresh seawater and clove oil (active ingredient: eugenol), which is a commonly used fish anesthetic (Sladky et al. 2001, Hiscock et al. 2002, Parsons et al. 2003, Cotter \& Rodruck 2006), and measured for standard length (SL). The transmitter was inserted into the body cavity through a $10 \mathrm{~mm}$ incision that was made between the pelvic and anal fins following a procedure similar to Nowak \& Quinn (2002). The incision was closed with 2 stitches using a C-curved needle with attached suture. A small sample of the dorsal fin tissue $\left(\sim 1 \mathrm{~cm}^{2}\right)$ was removed from each fish for stable isotope analysis (see below) before the fish was transferred to a cooler with fresh seawater for recovery. After $\sim 1 \mathrm{~h}$, the fish were released at the capture location. Fin clips were transported on ice to a field station, stored in a freezer and later processed at Florida International University.

To quantify presence/absence patterns at the 2 home sites, 1 stationary omnidirectional hydrophone (VR2, Vemco) was placed at each location. The receivers were secured to cinder blocks and placed on the substrate in the middle of both home sites at $\sim 1.5 \mathrm{~m}$ low tide depth. Since both home sites were surrounded by dense mangroves, detection ranges did not extend beyond the edges of the pools (C. HammerschlagPeyer unpubl. data).

To estimate movement outside the home sites, tagged fish were located from an inflatable Zodiac boat using a hand-held receiver and hydrophone (VR100, Vemco). The hydrophone was situated in the water column about halfway between the substrate and the water surface to minimize acoustic disturbances. Once a fish was detected, the coordinates of its position and the time of detection were recorded by the manual receiver. Mobile tracking was conducted every day at high tide for an entire lunar cycle, from 26 April to 24 May 2009. Because most parts of the creek are largely intertidal (and thus very shallow at low tide, with no fish movement), manual tracking was conducted $2 \mathrm{~h}$ before until $2 \mathrm{~h}$ after high tide. Tracking paths were chosen haphazardly during each session.

Data analysis. Continuous data from stationary receivers was categorized into 'time in' and 'time out' of the home site for each individual fish. If an individual was not detected by a stationary receiver for $>60 \mathrm{~min}$, the fish was considered to have left the tidal pool. For each fish, the home site, date, time in and time out were identified. Tracking with the manual receiver was used to identify the location of fish outside the home sites during each daily high tide. If $>1$ location fix (outside of the home sites) was obtained for an individual per tidal cycle, we used the fix with the highest detection strength $(\mathrm{dB})$ as an estimate of its most precise location during that given detection period. This procedure eliminated the problem of autocorrelation of successive detections (Van den Avyle \& Evans 1990, Sackett et al. 2007).

To determine mean distance moved, maximum distance moved and furthest distance away from the home site for each individual, the stationary and mobile tracking data were combined. Euclidean distance between 2 successive locations (typically between a home site and the strongest detection from the manual receiver) was estimated using ArcMap GIS version 9.3.1 (ESRI 2008). The mean distance moved by an individual was calculated by dividing its total distance moved during the study period by the total number of tidal cycles in which a movement of that individual occurred (e.g. Roth \& Greene 2006, Carfagno \& Weatherhead 2008). The maximum distance moved by an individual was the longest distance it moved during a single tidal cycle. This measure usually included a movement from one of the tidal pools to some location in the tidal creek and then back to a tidal pool during the same tidal cycle. The furthest distance away from the home site was the greatest distance that a fish was ever detected away from the home site during the study period. 
Activity space was defined as the area that a fish utilized during daytime tracking for the duration of the entire study period. It was estimated using the minimum convex polygon (MCP), i.e. the area of the smallest convex polygon that contains all observed positions of an individual fish (Anderson 1982). MCP estimations were obtained using Animal Movements extension (Hooge \& Eichenlaub 1997) for ArcView GIS version 3.2 (ESRI 1999). Areas of MCP that extended onto land were clipped using ArcMap Geoprocessing tools. The total activity space of each population was calculated by combining movement data for all 20 individuals of each species.

Fin tissues were analyzed for their $\delta^{13} \mathrm{C}$ values, as $\delta^{13} \mathrm{C}$ reflects long-term diet and may be used to indicate foraging areas (Layman 2007). In Bahamas tidal creek systems, prey $\delta^{13} \mathrm{C}$ values vary predictably from upper reaches of creek systems to creek mouths (authors' unpubl. data). Snapper prey at the creek mouth are relatively enriched in $\delta^{13} \mathrm{C}$ relative to prey that are typically found in the upper reaches of creeks (see Fig. 4); thus, $\delta^{13} \mathrm{C}$ values of snapper fin tissue may reflect long-term feeding in particular parts of the creek system. Analysis was based on Post et al. (2007) and was conducted at the Yale Earth System Center for Stable Isotopic Studies (ESCSIS). All stable isotope values are reported in the $\delta$ notation, where

$$
\delta^{13} \mathrm{C}=\left[\left(R_{\text {sample }} / R_{\text {standard }}\right)-1\right] \times 1000,
$$

and $R$ is the ${ }^{13} \mathrm{C} /{ }^{12} \mathrm{C}$ ratio.

Statistical analysis. For some individuals, we had a small number of observations likely because a fish might have died or left the study area. Linear regression revealed that all of our response measures were not significantly related to sample size when individuals with $<9$ observation points were excluded from each analysis $(\mathrm{p}>0.05)$, so each of these individuals was excluded. Additionally, it is also important to note that the number of individuals for a given analysis sometimes differed because of the way the individual observation points were used. For example, while 2 data points of each fish were used in the analysis of activity space and individual specialization, the same 2 points resulted in only 1 distance estimate for that fish. In sum, 14 gray and 15 schoolmaster snapper were used for the activity space and individual specialization analysis (see below), and 9 gray and 9 schoolmaster snapper were used for distance analysis.

Movement distances and activity space were examined as a function of body size using linear regression in SigmaPlot 10.0. When necessary to meet model assumptions, data were $\ln (x+0.5)$ transformed. Frequency histograms of movement distances and activity space were performed in $\mathrm{R}$ version 2.9.2. We examined a potential relationship between activity space and $\delta^{13} \mathrm{C}$ using linear regression.

Individual specialization. Recent studies have shown that intrapopulation variation in resource use can exist at a single ontogenetic life history stage (Bolnick et al. 2003). Individual specialization, which is defined as a significantly smaller (dietary) niche of an individual than the niche of its population for reasons not attributable to its sex, body size, or discrete morphology, has been identified in a number of diverse taxa (Ringler 1983, Magurran 1986, Schindler et al. 1997, Bolnick et al. 2003). One way to infer the occurrence of individual specialists in a population is by examining components of niche variation following Roughgarden $(1972,1974,1979)$. In this approach, the population's total niche width (TNW) in terms of resource use is subdivided into a within-individual component (WIC) and a between-individual component (BIC). Individual specialists occur in a population when the TNW consists mostly of the BIC, such that WIC/TNW is small (Roughgarden 1972, 1974, 1979). Most studies on individual specialization have focused on differences in diet and morphology (Bolnick et al. 2003, Araujo et al. 2007, Svanbäck \& Bolnick 2007, Svanbäck et al. 2008, Quevedo et al. 2009). Herein, we extend this framework to examine movement data.

In this analysis, the tidal creek was divided into 7 zones (the equivalent of individual diet items in traditional specialization studies) according to their habitat composition (Fig. S1 in the supplement available at www.int-res.com/articles/suppl/m415p211_supp.pdf), water depth, and distance from home sites A and B (Fig. 1). To calculate WIC/TNW, we used the number of detections of an individual fish in each zone during the entire study period. Individual specialization is likely to be present if the WIC/TNW value differs significantly from a null expectation. To this end, the movementbased WIC/TNW value for each population was tested against a null-model using a nonparametric Bootstrap Monte Carlo simulation (Text S1 in the supplement). Calculations were performed in IndSpec1 (Bolnick et al. 2002).

\section{RESULTS}

The 20 gray and 20 schoolmaster snapper had mean SLs of $168.5 \pm 43.4 \mathrm{~mm}$ (mean $\pm \mathrm{SD}_{\text {; }}$ range $111-276 \mathrm{~mm}$; Table S1 in the supplement) and $148.3 \pm 33.7 \mathrm{~mm}$ (range: 110-272 mm), respectively. Based on otolith readings, the body size range in this study included fish of ages 1 to 7 for gray snapper (Rypel \& Layman 2008) and 2 to 8 for schoolmaster snapper (A. Rypel, University of Alabama unpubl. data), and included sexually mature individuals (>185-195 mm SL for gray 
Table 1. Lutjanus griseus and L. apodus. Influence of body size on habitat use measures for gray snapper (GS) and schoolmaster snapper (SM), based on linear regressions. HS: home site

\begin{tabular}{|lclrc|}
\hline Measure & Species & $\mathrm{R}^{2}$ & Slope & $\mathrm{p}$-value \\
\hline Mean distance moved & GS & 0.03 & -0.25 & 0.64 \\
& $\mathrm{SM}$ & 0.4 & 1.03 & 0.07 \\
Max distance moved & GS & 0.03 & -0.67 & 0.68 \\
& $\mathrm{SM}$ & 0.36 & 2.17 & 0.09 \\
\multirow{4}{*}{ Furthest distance from HS } & GS & 0.06 & -0.84 & 0.55 \\
& $\mathrm{SM}$ & 0.07 & 0.48 & 0.49 \\
Minimum convex polygon & GS & 0.04 & -0.01 & 0.50 \\
& $\mathrm{SM}$ & 0.15 & 0.02 & 0.15 \\
\hline
\end{tabular}

snapper, Starck \& Schroeder 1971, and > 250 mm FL for schoolmaster snapper, Munro 1983). Based on length-weight regressions from tidal creeks on Abaco Island (C. Hammerschlag-Peyer unpubl. data), the SL range corresponded to body weights between 39 and $533 \mathrm{~g}$ for gray snapper and between 37 and $571 \mathrm{~g}$ for schoolmaster snapper. A total of 295621 individual detections were recorded by stationary and manual receivers for these 40 fishes. All individuals were detected at least once at the home sites by the stationary receivers, and 17 gray and 18 schoolmaster snapper were detected outside the home sites using the manual receiver. Body size had no significant effect on any habitat use measure in both gray and schoolmaster snapper (Table 1). Most schoolmaster snapper stayed near the home sites throughout the study period. Only 3 of the 20 schoolmaster snapper and 7 of the 20 gray snapper were detected outside the zones immediately adjacent to the home sites (Fig. 1).

A few individuals in both populations utilized large areas, whereas most individuals were characterized by small activity spaces (Fig. 2G,H). The MCP estimates of the total activity space were $145837 \mathrm{~m}^{2}$ for 14 gray snapper and $46565 \mathrm{~m}^{2}$ for 15 schoolmaster snapper. Eleven gray and 12 schoolmaster snapper used $<10 \%$ of the total activity space for each population, while 3 gray and 3 schoolmaster snapper used between 40 to $60 \%$ and 20 to $35 \%$ of the total activity space, respectively. Importantly, activity spaces differed also among individuals by their spatial orientation and location in the creek (e.g. Fig. 3). These data suggest that movements and habitat use among individuals varied substantially.

The WIC/TNW of gray and schoolmaster snapper equaled 0.34 and 0.47 , respectively, with the BIC being larger than the WIC in both cases. The WIC/TNW index for both populations was significantly different from the null model ( $p<0.001)$, which provides evidence for individual specialization in habitat use (Bolnick et al. 2002). Specialization is evident when look- ing more closely at the differential habitat use of individual fish. For instance, 4 gray and 5 schoolmaster snapper only utilized 1 home site area during the entire study period and were never observed outside the home site areas. The 7 gray and 3 schoolmaster snapper that utilized other zones of the creek tended to move to the same areas repeatedly, with areas differing among individuals (Table 2). Four gray and 2 schoolmaster snapper moved to only 1 zone in addition to the home sites.

The $\delta^{13} \mathrm{C}$ values of schoolmaster snapper were significantly related to the size of the activity space $\left(\mathrm{R}^{2}=\right.$ $0.31, \mathrm{p}=0.03$ ), with individuals with small activity spaces having more depleted $\delta^{13} \mathrm{C}$ values (Fig. 4B). The $\delta^{13} \mathrm{C}$ values of gray snapper became more enriched with increased activity space utilization, but this positive relationship was not statistically significant $\left(\mathrm{R}^{2}=\right.$ 0.15, $\mathrm{p}=0.19$; Fig. 4A). These patterns are consistent with the $\delta^{13} \mathrm{C}$ values of prey in upper and lower portions of the creek. Individual snapper that moved further (i.e. had large activity spaces extending toward the ocean) tended to have enriched $\delta^{13} \mathrm{C}$ values similar to prey collected at the mouths of creeks (i.e. marine influences). This likely reflects a food web module originating from seagrass or seagrass epiphytes (that tend to be relatively enriched in $\delta^{13} \mathrm{C}$ ). Snapper individuals that moved less had more depleted $\delta^{13} \mathrm{C}$ values. These values were similar to those of prey collected in portions of creeks adjacent to the home sites, likely reflecting feeding pathways originating from micro- and macroalgae that are abundant in these areas (Kieckbusch et al. 2004).

\section{DISCUSSION}

Populations are usually considered to be homogeneous entities, with variation among individuals often not being incorporated into ecological studies. Our data suggest that there may be substantial small-scale intrapopulation variability in movement patterns in gray and schoolmaster snapper. In both populations, some individuals moved repeatedly outside of the home sites, while others remained in or near the deep pools for the entire study period. The activity space of individual fish also differed based on spatial orientation and location. Such intrapopulation variation has been shown to be important in several freshwater fish taxa (Bourke et al. 1997, Morbey et al. 2006, Kobler et al. 2009), and we provide one of the first extensions of this research framework to marine fishes (cf. Egli \& Babcock 2004).

Intrapopulation variations in movement patterns and habitat use were generally not explained by body size even though the body size range in this study included 
juvenile and adult individuals. Body size is widely accepted as a driver of intrapopulation variation in fish habitat utilization (e.g. Minns 1995). However, our results support recent research findings that indicated no effect of body size on intraspecific patterns of home range/activity space (Lowry \& Suthers 1998, Weller \& Winter 2001, Sakaris et al. 2003, Morbey et al. 2006)
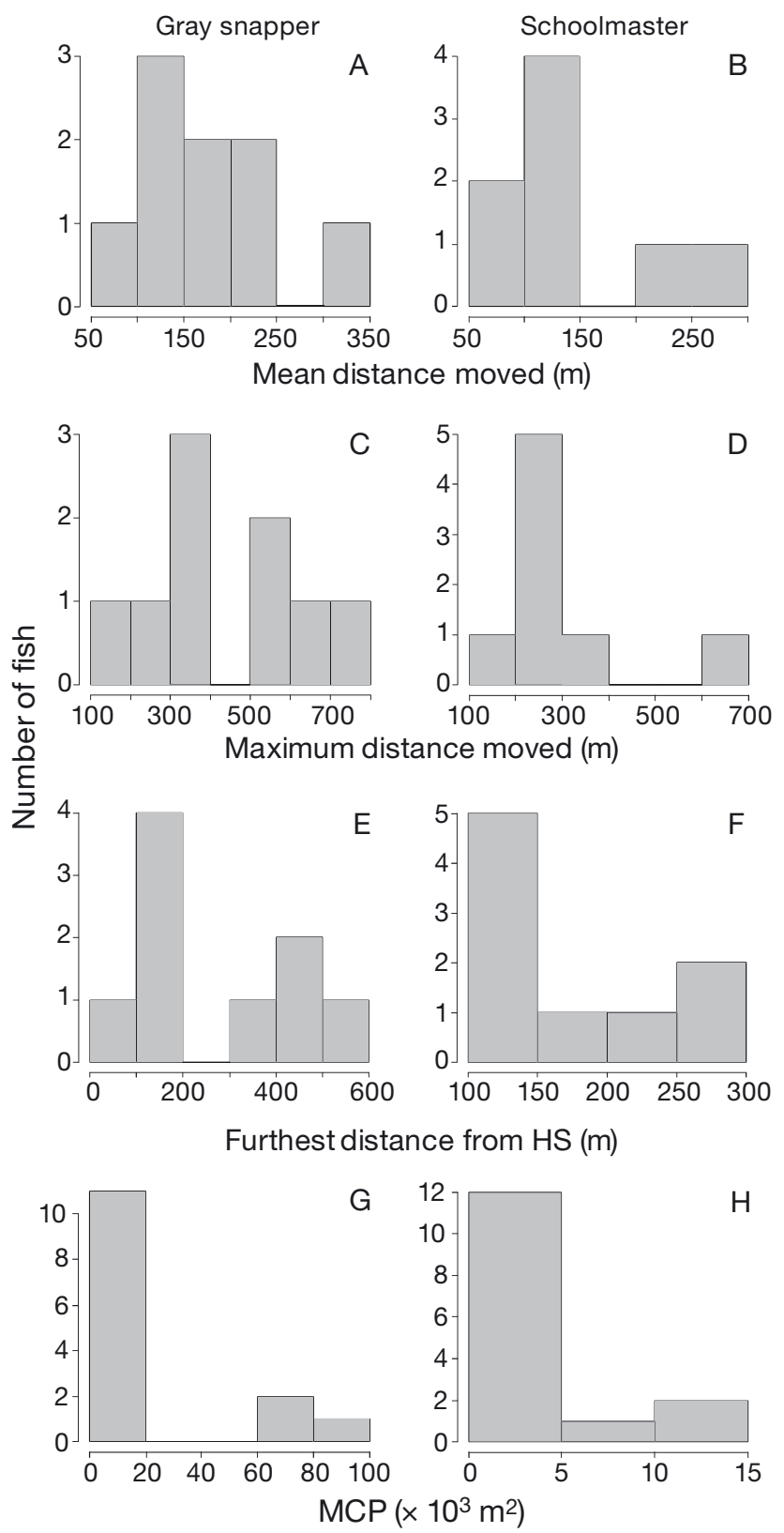

Fig. 2. Lutjanus griseus and L. apodus. Frequency histograms of (1) mean distance moved (average of daily movement distances, 26 April - 24 May 2009) (A-B); (2) maximum distance moved (C-D); (3) furthest distance away from home sites (HS; $\mathrm{E}-\mathrm{F})$; and (4) activity space based on minimum convex polygon $(\mathrm{MCP})$ estimates $(\mathrm{G}-\mathrm{H})$. Left panels: results for gray snapper, right panels: results for schoolmaster snapper and movement patterns (Bourke et al. 1997, Egli \& Babcock 2004, Ng et al. 2007, Childs et al. 2008, Koster $\&$ Crook 2008). Only the mean and maximum distances moved by schoolmaster snapper were marginally significant $(0.1>p>0.05$; Table 1$)$, likely because 3 of the larger individuals moved outside the home site zones (Fig. 1). These findings could be affected by the inherently small sample size that is common in telemetry studies due to costs associated with tagging technology (Luo et al. 2009). Despite this limitation, we demonstrated that intrapopulation differences in movement patterns of marine fishes may be greater than has previously been recognized and that factors other than body size may drive much of this variation.

In back reef systems, seascape attributes have been shown to be a primary determinant of habitat use of fishes (Pittman et al. 2007). Many coastal fishes, including snapper, generally prefer mangroves surrounded by dense seagrass (Pittman et al. 2007) since mangrove prop roots provide shelter (Hammerschlag et al. 2010) and seagrass beds contain high densities of prey items for coastal fishes (Orth et al. 1984). In the present study system, potential resource pools, such as seagrass, were patchily distributed across the creek system. Such a heterogeneous matrix of resources provides a large scope for individuals to develop specialized movement patterns. This contrasts with systems

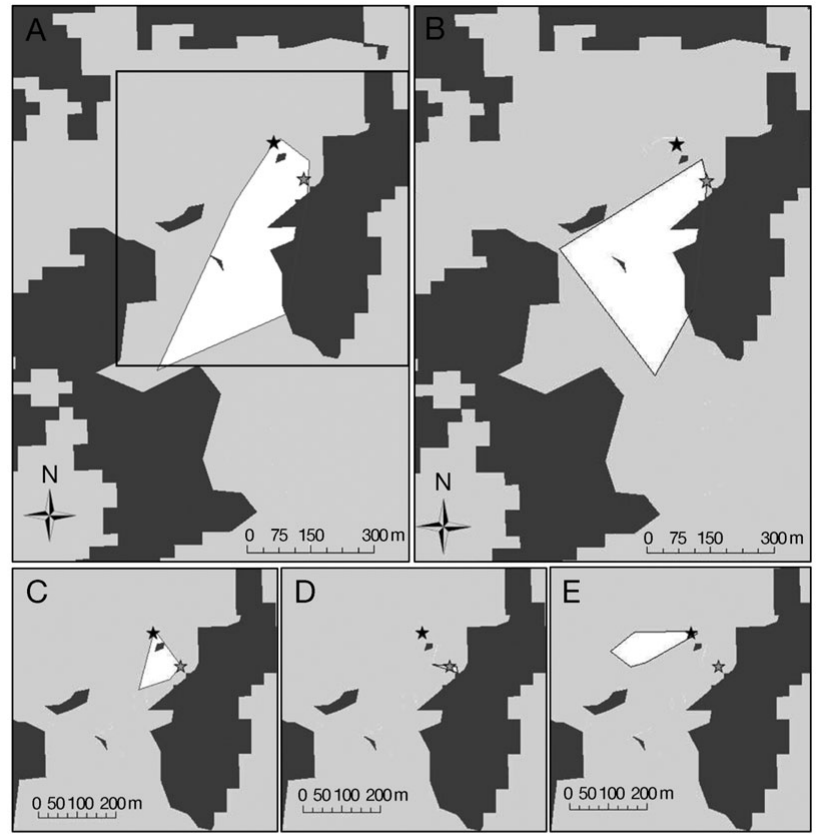

Fig. 3. Lutjanus griseus and L. apodus. Examples of the activity space for 5 ind. (gray snappers: A-C; schoolmaster snappers: $\mathrm{D}-\mathrm{E}$ ) in the study area (dark gray: land, light gray: aquatic habitat) from 26 April to 24 May 2009. (Black frame) in (A) corresponds to the area represented in the smaller maps (C-E) 
Table 2. Lutjanus griseus and L. apodus. Total number of days on which gray snapper (GS) and schoolmaster snapper (SM) moved outside the home sites and the percentage of trips when each individual visited the different creek zones (see 'Results. Individual specialization' and Fig. 1 for more details). Total number of days is smaller than the actual number of observation points per individual because observations in home site areas are excluded here (see Table S1 in the supplement available at www.int-res.com/articles/suppl/m415p211_supp.pdf for more details)

\begin{tabular}{|c|c|c|c|c|c|c|c|}
\hline ID & Species & $\begin{array}{c}\text { Total no. } \\
\text { of days }\end{array}$ & $\begin{array}{c}\% \text { to south } \\
\text { west margin }\end{array}$ & $\begin{array}{l}\% \text { to west } \\
\text { margin }\end{array}$ & $\begin{array}{l}\% \text { to south } \\
\text { margin }\end{array}$ & $\begin{array}{l}\% \text { to } \\
\text { middle }\end{array}$ & $\begin{array}{l}\% \text { to } \\
\text { mouth }\end{array}$ \\
\hline 57223 & GS & 9 & 0 & 100 & 0 & 0 & 0 \\
\hline 57224 & GS & 1 & 0 & 100 & 0 & 0 & 0 \\
\hline 57229 & GS & 10 & 0 & 100 & 0 & 0 & 0 \\
\hline 57230 & GS & 3 & 0 & 0 & 33 & 67 & 0 \\
\hline 57245 & GS & 3 & 0 & 0 & 0 & 100 & 0 \\
\hline 58468 & GS & 7 & 29 & 0 & 0 & 57 & 14 \\
\hline 58474 & GS & 17 & 88 & 0 & 0 & 12 & 0 \\
\hline 57221 & SM & 9 & 0 & 100 & 0 & 0 & 0 \\
\hline 57222 & SM & 2 & 0 & 50 & 0 & 50 & 0 \\
\hline 58469 & SM & 1 & 0 & 0 & 0 & 100 & 0 \\
\hline
\end{tabular}

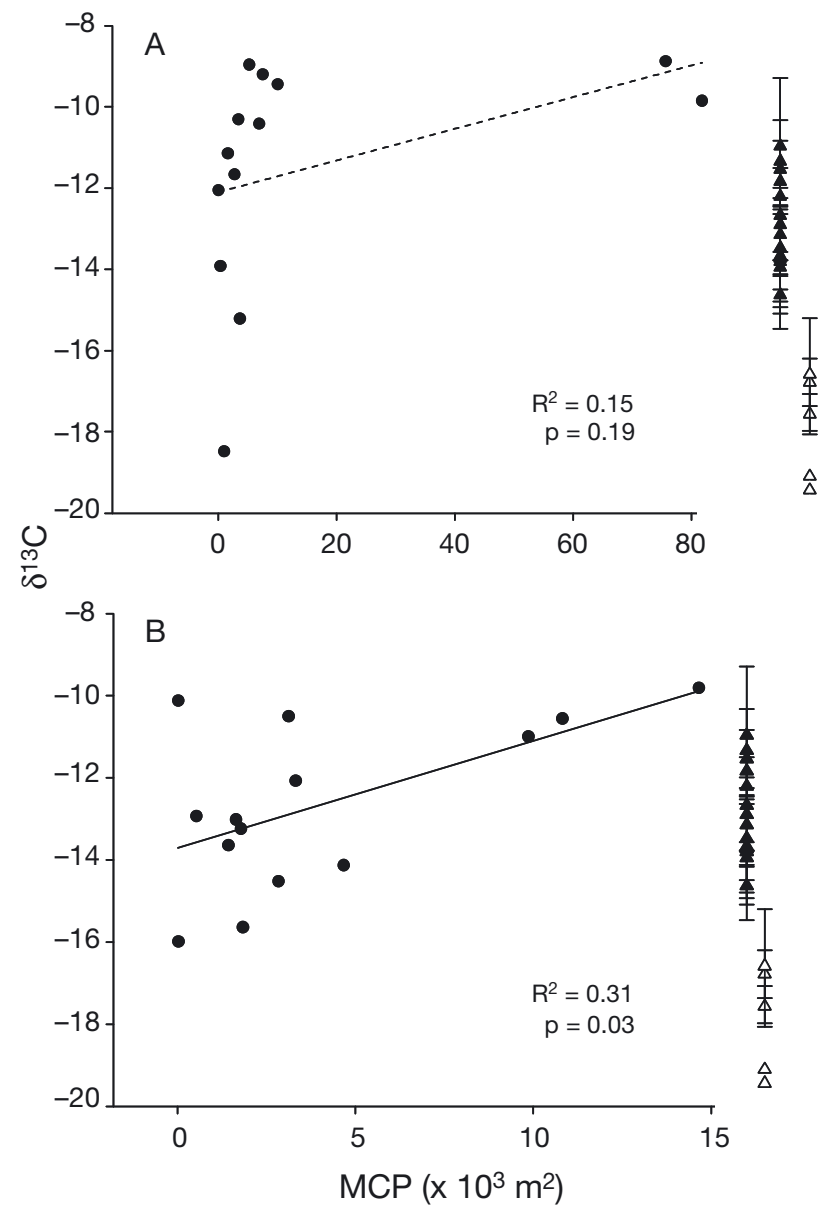

Fig. 4. Linear regression between $\delta^{13} \mathrm{C}$ and activity space (minimum convex polygon, MCP) for (A) gray snapper and (B) schoolmaster snapper. (•) Data for an individual snapper. Triangles represent mean $\delta^{13} \mathrm{C}$ values for individual taxa that are known to be snapper prey (error bars: SDs). The $\delta^{13} \mathrm{C}$ values of prey items vary between $(\boldsymbol{\Delta})$ creek mouth and $(\Delta)$ upstream areas. The $\delta^{13} \mathrm{C}$ values of prey items were corrected for trophic discrimination (1\%o, according to Post 2002) where resources are concentrated in a single location. For example, schoolmaster snapper in Spanish Water Bay, Curaçao, typically move $<5 \mathrm{~m}$ during the day (Verweij et al. 2007), perhaps because dense seagrass beds are found immediately adjacent to fringing mangroves. In this context, distinct movement patterns among individuals may be less likely to develop because of the concentration of food resources. Alternatively, the relatively short movement distances of schoolmaster snapper in Spanish Water Bay could also be because they feed and seek shelter in mangroves during the day, and feed in adjacent seagrass beds at night (Nagelkerken \& van der Velde 2004, Verweij et al. 2006), probably to minimize predation risk (e.g. Laegdsgaard \& Johnson 1995). Predation pressure might be higher in Spanish Water Bay than in our study system (we did not quantify this variable), and is another factor that must be considered when analyzing movement distances of individual fish.

Several contexts could be used to elucidate the intrapopulation variation in habitat use. The simplest explanation is that individuals moved randomly, thereby creating habitat use variation among individuals. However, repeated use of certain zones by the same individuals does not seem to support this explanation. Alternatively, movement patterns of individuals may relate to optimal foraging (MacArthur \& Pianka 1966) in conjunction with differential learning among individuals (Brown \& Laland 2003). In this context, it could be more beneficial for certain individuals to forage in proximity to the home sites, while others maximize their intake by foraging in other areas of the creek. Differential habitat use patterns among individuals are also consistent with the 'boldness versus shyness' dichotomy of behavioral traits (Gosling \& John 1999, Gosling 2001), which is a pattern that is found in 
many fish species (Sih et al. 2004a, Sih et al. 2004b). Bold individuals would be those that frequently explore other habitats or zones, while shy ones remain in proximity to their home sites (Russell 1983, Wilson et al. 1993).

An underlying driver for the above-mentioned contexts of intrapopulation habitat variation could be differential responses of individuals to competition. Specialization in movement patterns and habitat use is most likely when intraspecific competition is high (Svanbäck et al. 2008), and our empirical data may provide such an example in a marine system. Because all individuals are forced into the home sites at low tide, competition for food resources is likely high (Whitham 1978). Fishes that move further may be able to access underutilized food resources in patchily distributed seagrass beds outside the home site zones, with a trade-off of increased predation risk and energy expenditure (MacArthur \& Pianka 1966).

Snapper $\delta^{13} \mathrm{C}$ values tended to be more enriched in individuals that had large activity spaces. For both species, individuals that used large activity spaces (i.e. moved further toward the ocean) had similar $\delta^{13} \mathrm{C}$ values to prey collected from creek mouths, while individuals with small activity spaces tended to have more depleted $\delta^{13} \mathrm{C}$ values. These findings suggest that individuals with large activity spaces were feeding from a more marine-based food web module, likely originating in seagrass beds $\left(\delta^{13} \mathrm{C}=-10.5 \pm 2.5\right.$; Kieckbusch et al. 2004). In contrast, individuals with small activity spaces seem to feed on prey in the upstream portion of the creek (at and around the home sites), likely based on diverse macro- and microalgal assemblages $\left(\delta^{13} \mathrm{C}=\right.$ $-18.0 \pm 5.4$, Kieckbusch et al. 2004). Patterns in tissue $\delta^{13} \mathrm{C}$ provide strong evidence that the movement patterns that were observed over the course of the $4 \mathrm{wk}$ study period were reflective of longer-term feeding trends (Hesslein et al. 1993, Suring \& Wing 2009).

Fisheries management strategies have often ignored intrapopulation variation in marine systems. Simply concentrating on the 'typical' habitats of a fish population may inherently ignore those individuals that use alternative habitats or food sources (Durell 2000, Bolnick et al. 2003). For instance, in a New Zealand marine protected area (MPA), $50 \%$ of New Zealand snapper Pagrus auratus remained within the area during the research period. However, the remaining individuals spent most of their time outside the reserve (Egli \& Babcock 2004). This MPA would only provide protection for those individuals that moved less through time. Such cases and the present study suggest that a shift in perspective-from a population to an individual level-may be warranted in the management of some marine fisheries. Such an approach may help preserve species' ecological, phenotypic and genetic diversity, and thus their ability to adapt to environmental change and to human impacts in marine ecosystems (Moritz 1994, Coates 2000, Smith et al. 2001, Bolnick et al. 2003).

\begin{abstract}
Acknowledgements. This project was conducted as part of a broad educational outreach program funded by NSF OCE \#0746164, NSF DEB \#0842196, the MacTaggart Third Fund, Friends of the Environment (Abaco), and the Bahamas Reef Environmental Education Foundation. Dozens of Bahamian students were involved in catching their 'own' fish and tracking the fishes' movements through time. We thank Friends of the Environment for their logistical support and all people who helped with field work, data analysis, and manuscript editing, including S. Whitcraft, S. Hurley, G. Mineau, K. Bernhardt, M. Ioli, J. Allgeier, M. Araujo, N. Hammerschlag, L. Yeager, S. Giery, E. Stoner, Z. Jud, and P. Matich.
\end{abstract}

\section{LITERATURE CITED}

Allen GR (1985) FAO species catalogue. Vol 6. Snappers of the world. An annotated and illustrated catalogue of lutjanid species known to date. FAO Fish Synop No. 125, FAO, Rome

Anderson DJ (1982) The home range: a new nonparametric estimation technique. Ecology 63:103-112

Araujo MS, Bolnick DI, Machado G, Giaretta AA, dos Reis SF (2007) Using $\delta^{13} \mathrm{C}$ stable isotopes to quantify individuallevel diet variation. Oecologia 152:643-654

Baillie J, Groombridge B (1996) 1996 IUCN Red List of threatened animals. IUCN, Gland

Bolnick DI, Yang LH, Fordyce JA, Davis JM, Svanbäck R (2002) Measuring individual-level resource specialization. Ecology 83:2936-2941

Bolnick DI, Svanbäck R, Fordyce JA, Yang LH, Davis JM, Hulsey CD, Forister ML (2003) The ecology of individuals: incidence and implications of individual specialization. Am Nat 161:1-28

Bourke P, Magnan P, Rodriguez MA (1997) Individual variations in habitat use and morphology in brook charr. J Fish Biol 51:783-794

Brown C, Laland KN (2003) Social learning in fishes: a review. Fish Fish 4:280-288

Carfagno GLF, Weatherhead PJ (2008) Energetics and space use: intraspecific and interspecific comparisons of movements and home ranges of two colubrid snakes. J Anim Ecol 77:416-424

Childs AR, Cowley PD, Naesje TF, Booth AJ, Potts WM, Thorstad EB, Okland F (2008) Do environmental factors influence the movement of estuarine fish? A case study using acoustic telemetry. Estuar Coast Shelf Sci 78: $227-236$

Coates DJ (2000) Defining conservation units in a rich and fragmented flora: implications for the management of genetic resources and evolutionary processes in southwest Australian plants. Aust J Bot 48:329-339

Coleman FC, Figueira WF, Ueland JS, Crowder LB (2004) The impact of United States recreational fisheries on marine fish populations. Science 305:1958-1960

Cotter PA, Rodruck KJ (2006) Differential effects of anesthetics on electrical properties of the rainbow trout (Oncorhynchus mykiss) heart. Comp Biochem Physiol A 145: 158-165

Durell SE (2000) Individual feeding specialisation in shore- 
birds: population consequences and conservation implications. Biol Rev Camb Philos Soc 75:503-518

Egli DP, Babcock RC (2004) Ultrasonic tracking reveals multiple behavioural modes of snapper (Pagrus auratus) in a temperate no-take marine reserve. ICES J Mar Sci 61: $1137-1143$

ESRI (Environmental Systems Research Institute) (1999) ArcView GIS v. 3.2, Redlands, CA

ESRI (2008) ArcMap GIS v. 9.3. ESRI, Redlands, CA

- Gosling SD (2001) From mice to men: What can we learn about personality from animal research? Psychol Bull 127: 45-86

Gosling SD, John OP (1999) Personality dimensions in nonhuman animals: a cross-species review. Curr Dir Psychol Sci 8:69-75

- Graham RT, Carcamo R, Rhodes KL, Roberts CM, Requena N (2008) Historical and contemporary evidence of a mutton snapper (Lutjanus analis Cuvier, 1828) spawning aggregation fishery in decline. Coral Reefs 27:311-319

Hammerschlag N, Morgan AB, Serafy JE (2010) Relative predation risk for fishes along a subtropical mangrove-seagrass ecotone. Mar Ecol Prog Ser 401:259-267

$>$ Heithaus MR, Frid A, Wirsing AJ, Worm B (2008) Predicting ecological consequences of marine top predator declines. Trends Ecol Evol 23:202-210

Hesslein RH, Hallard KA, Ramlal P (1993) Replacement of sulfur, carbon, and nitrogen in tissue of growing broad whitefish (Corgonus nasus) in response to a change in diet traced by $\delta^{34} \mathrm{~S}, \delta^{13} \mathrm{C}$, and $\delta^{15} \mathrm{~N}$. Can J Fish Aquat Sci 50: 2071-2076

Hiscock MJ, Scruton DA, Brown JA, Pennell CJ (2002) Diel activity pattern of juvenile Atlantic salmon (Salmo salar) in early and late winter. Hydrobiologia 483:161-165

Hooge PN, Eichenlaub B (1997) Animal movement extension to Arcview ver. 1.1. Alaska Science Center, Biological Science Office, US Geological Survey, Anchorage, AK

> Huijbers CM, Mollee EM, Nagelkerken I (2008) Post-larval French grunts (Haemulon flavolineatum) distinguish between seagrass, mangrove and coral reef water: implications for recognition of potential nursery habitats. J Exp Mar Biol Ecol 357:134-139

Jackson JBC, Kirby MX, Berger WH, Bjorndal KA and others (2001) Historical overfishing and the recent collapse of coastal ecosystems. Science 293:629-638

Kieckbusch DK, Koch MS, Serafy JE, Anderson WT (2004) Trophic linkages among primary producers and consumers in fringing mangroves of subtropical lagoons. Bull Mar Sci 74:271-285

Kobler A, Klefoth T, Mehner T, Arlinghaus R (2009) Coexistence of behavioural types in an aquatic top predator: a response to resource limitation? Oecologia 161:837-847

Koster WM, Crook DA (2008) Diurnal and nocturnal movements of river blackfish (Gadopsis marmoratus) in a southeastern Australian upland stream. Ecol Freshw Fish 17: $146-154$

Laegdsgaard P, Johnson CR (1995) Mangrove habitats as nurseries: unique assemblages of juvenile fish in subtropical mangroves in eastern Australia. Mar Ecol Prog Ser 126:67-81

Layman CA (2007) What can stable isotope ratios reveal about mangroves as fish habitat? Bull Mar Sci 80:513-527

> Layman CA, Quattrochi JP, Peyer CM, Allgeier JE (2007) Niche width collapse in a resilient top predator following ecosystem fragmentation. Ecol Lett 10:937-944

Lotze HK, Worm B (2009) Historical baselines for large marine animals. Trends Ecol Evol 24:254-262

Lowry MB, Suthers IM (1998) Home range, activity and distri- bution patterns of a temperate rocky-reef fish, Cheilodactylus fuscus. Mar Biol 132:569-578

Luo JG, Serafy JE, Sponaugle S, Teare PB, Kieckbusch D (2009) Movement of gray snapper Lutjanus griseus among subtropical seagrass, mangrove, and coral reef habitats. Mar Ecol Prog Ser 380:255-269

> MacArthur RH, Pianka ER (1966) On optimal use of a patchy environment. Am Nat 100:603-609

Magurran AE (1986) Individual differences in fish behaviour. In: Pitcher TJ (ed) The behaviour of teleost fishes. Croom Helm, London, p 338-365

- Meyer JL, Schultz ET, Helfman GS (1983) Fish schools: an asset to corals. Science 220:1047-1049

> Minns CK (1995) Allometry of home-range size in lake and river fishes. Can J Fish Aquat Sci 52:1499-1508

> Morbey YE, Addison P, Shuter BJ, Vascotto K (2006) Withinpopulation heterogeneity of habitat use by lake trout Salvelinus namaycush. J Fish Biol 69:1675-1696

Moritz C (1994) Application of mitochondrial DNA analysis in conservation: a critical review. Mol Ecol 3:401-411

Munro JL (1983) Caribbean coral reef fishery resources. ICLARM, Manila

Nagelkerken I, van der Velde G (2004) Relative importance of interlinked mangroves and seagrass beds as feeding habitats for juvenile reef fish on a Caribbean island. Mar Ecol Prog Ser 274:153-159

> Nagelkerken I, Dorenbosch M, Verberk W, de la Moriniere EC, van der Velde G (2000) Importance of shallow-water biotopes of a Caribbean bay for juvenile coral reef fishes: patterns in biotope association, community structure and spatial distribution. Mar Ecol Prog Ser 202:175-192

> Ng CL, Able KW, Grothues TM (2007) Habitat use, site fidelity, and movement of adult striped bass in a southern New Jersey estuary based on mobile acoustic telemetry. Trans Am Fish Soc 136:1344-1355

Nieland DL, Wilson CA, Fischer AJ (2007) Declining size at age among red snapper in the northern Gulf of Mexico off Louisiana, USA: recovery or collapse? In: Patterson WF, Cowan JH, Fitzhugh GR, Nieland DL (eds) Red snapper ecology and fisheries in the US Gulf of Mexico. Am Fish Soc Symp 60:329-336

Nowak GM, Quinn TP (2002) Diel and seasonal patterns of horizontal and vertical movements of telemetered cutthroat trout in Lake Washington, Washington. Trans Am Fish Soc 131:452-462

> Orth RJ, Heck KL, Vanmontfrans J (1984) Faunal communities in seagrass beds: a review of the influence of plant structure and prey characteristics on predator-prey relationships. Estuaries 7:339-350

Parsons DM, Babcock RC, Hankin RKS, Willis TJ, Aitken JP, O'Dor RK, Jackson GD (2003) Snapper Pagrus auratus (Sparidae) home range dynamics: acoustic tagging studies in a marine reserve. Mar Ecol Prog Ser 262:253-265

Pauly D, Christensen V, Dalsgaard J, Froese R, Torres F (1998) Fishing down marine food webs. Science 279: 860-863

> Pittman SJ, Caldow C, Hile SD, Monaco ME (2007) Using seascape types to explain the spatial patterns of fish in the mangroves of SW Puerto Rico. Mar Ecol Prog Ser 348: 273-284

Post DM (2002) Using stable isotopes to estimate trophic position: models, methods, and assumptions. Ecology 83: 703-718

> Post DM, Layman CA, Arrington DA, Takimoto G, Quattrochi J, Montana CG (2007) Getting to the fat of the matter: models, methods and assumptions for dealing with lipids in stable isotope analyses. Oecologia 152:179-189 
Quevedo M, Svanbäck R, Eklov P (2009) Intrapopulation niche partitioning in a generalist predator limits food web connectivity. Ecology 90:2263-2274

Ringler NH (1983) Variation in foraging tactics in fishes. In: Noakes DLG, Lindquist DG, Helfman GS, Ward JA (eds) Predation and prey in fishes. Junk, Hague, p 159-171

Roth TC, Greene BD (2006) Movement patterns and home range use of the northern watersnake (Nerodia sipedon). Copeia 3:544-551

Roughgarden J (1972) Evolution of niche width. Am Nat 106: 683-718

Roughgarden J (1974) Niche width: biogeographic patterns among anolis lizard populations. Am Nat 108:429-442

Roughgarden J (1979) Theory of population genetics and evolutionary ecology: an introduction. Macmillan, New York, NY

Russell PA (1983) Psychological studies of exploration in animals: a reappraisal. In: Birke LIA, Archer J (eds) Exploration in animals and humans. Van Nostrand, New York, NY, p 22-54

Rypel AL, Layman CA (2008) Degree of aquatic ecosystem fragmentation predicts population characteristics of gray snapper (Lutjanus griseus) in Caribbean tidal creeks. Can J Fish Aquat Sci 65:335-339

Rypel AL, Layman CA, Arrington DA (2007) Water depth modifies relative predation risk for a motile fish taxon in Bahamian tidal creeks. Est Coasts 30:518-525

Sackett DK, Able KW, Grothues TM (2007) Dynamics of summer flounder, Paralichthys dentatus, seasonal migrations based on ultrasonic telemetry. Estuar Coast Shelf Sci 74: 119-130

Sadovy YJ (1997) The case of the disappearing grouper: Epinephelus striatus, the Nassau grouper in the Caribbean and western Atlantic. Proc Gulf Caribb Fish Inst 45:5-22

Sakaris PC, Ferrara AM, Kleiner KJ, Irwin ER (2003) Movements and home ranges of alligator gar in the Mobile-Tensaw Delta, Alabama. Proc Annu Conf Southeast Assoc Fish and Wildl Agencies 57:102-111

Schindler DE, Hodgson JR, Kitchell JF (1997) Densitydependent changes in individual foraging specialization of largemouth bass. Oecologia 110:592-600

Sih A, Bell A, Johnson JC (2004a) Behavioral syndromes: an ecological and evolutionary overview. Trends Ecol Evol 19:372-378

Sih A, Bell AM, Johnson JC, Ziemba RE (2004b) Behavioral syndromes: an integrative overview. Q Rev Biol 79:241-277

Sladky KK, Swanson CR, Stoskopf MK, Loomis MR, Lewbart GA (2001) Comparative efficacy of tricaine methanesulfonate and clove oil for use as anesthetics in red pacu (Piaractus brachypomus). Am J Vet Res 62:337-342

Smith TB, Kark S, Schneider CJ, Wayne RK, Moritz C (2001) Biodiversity hotspots and beyond: the need for preserving

Editorial responsibility: Ivan Nagelkerken, Nijmegen, Netherlands environmental transitions. Trends Ecol Evol 16:431

Starck WA, Schroeder RE (1971) Investigations on the gray snapper, Lutjanus griseus. University of Miami Press, Coral Gables, FL

Suring E, Wing SR (2009) Isotopic turnover rate and fractionation in multiple tissues of red rock lobster (Jasus edwardsii) and blue cod (Parapercis colias): consequences for ecological studies. J Exp Mar Biol Ecol 370:56-63

Svanbäck R, Bolnick DI (2007) Intraspecific competition drives increased resource use diversity within a natural population. Proc R Soc Lond B 274:839-844

Svanbäck R, Eklov P, Fransson R, Holmgren K (2008) Intraspecific competition drives multiple species resource polymorphism in fish communities. Oikos 117:114-124

Valentine-Rose L, Cherry JA, Culp JJ, Perez KE, Pollock JB, Arrington DA, Layman CA (2007a) Floral and faunal differences between fragmented and unfragmented Bahamian tidal creeks. Wetlands 27:702-718

Valentine-Rose L, Layman CA, Arrington DA, Rypel AL (2007b) Habitat fragmentation decreases fish secondary production in Bahamian tidal creeks. Bull Mar Sci 80: 863-877

- Van den Avyle MJ, Evans JW (1990) Temperature selection by striped bass in a Gulf of Mexico coastal river system. N Am J Fish Manag 10:58-66

Van Valen L (1965) Morphological variation and width of ecological niche. Am Nat 99:377-390

Verweij MC, Nagelkerken I, de Graaff D, Peeters M, Bakker EJ, van der Velde G (2006) Structure, food and shade attract juvenile coral reef fish to mangrove and seagrass habitats: a field experiment. Mar Ecol Prog Ser 306: $257-268$

Verweij MC, Nagelkerken I, Hol KEM, van den Beld A, van der Velde G (2007) Space use of Lutjanus apodus including movement between a putative nursery and a coral reef. Bull Mar Sci 81:127-138

Weller RR, Winter JD (2001) Seasonal variation in home range size and habitat use of flathead catfish in buffalo springs lake, Texas. N Am J Fish Manage 21:792-800

Whitham TG (1978) Habitat selection by pemphigus aphids in response to resource limitation and competition. Ecology 59:1164-1176

Willis TJ, Parsons DM, Babcock RC (2001) Evidence for longterm site fidelity of snapper (Pagrus auratus) within a marine reserve. N Z J Mar Freshw Res 35:581-590

Wilson DS, Coleman K, Clark AB, Biederman L (1993) Shybold continuum in pumpkinseed sunfish (Lepomis gibbosus): an ecological study of a psychological trait. J Comp Psychol 107:250-260

- Worm B, Barbier EB, Beaumont N, Duffy JE and others (2006) Impacts of biodiversity loss on ocean ecosystem services. Science 314:787-790

Submitted: March 24, 2010; Accepted: June 25, 2010

Proofs received from author(s): September 21, 2010 